\title{
Pathogenic bacteria and parasites of human importance from cow dung
}

\begin{abstract}
Cow dung is used commonly in rural and periurban households in India for many purposes like for cooking and mopping floors. However it can contain many pathogenic bacteria and parasites like Escherichia coli, Cryptosporidium spp. and Entamoeba histolytica that can be infectious to the handlers and farmers. Hence one should be very careful while handling these. Thus a study of pathogenic microbial flora in cow dung is of utmost public health importance in our country and very little literature is available regard it. Hence, we here have tried to summarize available information in this aspect.
\end{abstract}

Keywords: cow dung, bacteria, parasites, public health

\author{
Volume 6 Issue I - 202|
}

\author{
Chourasiya R, Bhattacharyya S, Dighe P, \\ Banik A, Raj A \\ Department of Microbiology, AllH\&PH, Kolkata
}

\begin{abstract}
Correspondence: Dr Sayan Bhattacharyya, Department of Microbiology, AllH\&PH, Kolkata, India, Tel +91-9006621729, Email sayantheboss@yahoo.co.in
\end{abstract}

Received: February 01, 2021 | Published: February 16, 2021

\section{Introduction}

Livestock dung and human pit have played an increasingly important role in agriculture of tropical Asian countries like India and Bangladesh. ${ }^{1}$ In India it is considered sacred and people can even consume it. Also, In North Indian States, cow-dung cake remain one of the major fuels for cooking for a major chunk of rural households in states like Uttar Pradesh and Punjab, Haryana and Bihar. ${ }^{2}$ Cow dung is a frequently used organic fertilizer and manure in rural India and in other neighbouring countries, and their manure potential is often not fully utilized. ${ }^{3}$ However there are issues regarding the hazards associated with use for fresh and dry cow dung samples. So it is very important to study and assess their safety before handling and use in day to day life.

\section{Chemical hazards of biofuel from cow dung}

Cow dung cakes are possibly the cheapest burning fuel rural people use for purposes of cooking. However, burning of dung cakes often causes serious health problems. According to health experts, the smoke released in the burning process contains many hazardous gases. ${ }^{4}$ Studies show that by inhaling these, people suffer from diseases. There are specially made chulhas or stoves for using of dung cakes. Usually these cakes consist of groundnut husk; paddy straw is also used. When the cakes are burnt, dangerous gases are produced which are inhaled and can cause respiratory ailments. ${ }^{4}$

Cattle manure is a storehouse of microbial constituents that make it a potential source of pollution in the environment and infections in humans. ${ }^{5}$ Knowledge of microbial flora and toxins in manure is thus very important in order to prevent public health and environmental hazards through the development of better management practices and policies that should target manure handling. Physical, chemical and biological methods to reduce pathogen population in manure are there, but are faced with challenges such as cost, odour pollution and green house gas emission. ${ }^{5}$

\section{Materials and methods}

Internet search was carried out for available scientific information worldwide regarding this. Also our own experience in this aspect was collated. We are carrying out this study where we made saline and Iodine mounts of fresh cow dung samples and also did modified Ziehl
Neelson stain for coccidia. Also we cultured undiluted and diluted cow dung samples on Mac Conkey agar for pathogenic bacteria.

\section{Cow dung as potential source of pathogenic parasites and bacteria}

Animal manure like freshly passed Cow dung is known to harbour a plethora of microorganisms which can be pathogenic to both animals and humans. ${ }^{6}$ Many pathogenic microbes are found in cow dung, but he extent to which they survive in the environment or manure depends basically on the characteristics of the particular organisms, the source and chemical composition of manure (like ammonium content), $\mathrm{pH}$, dry matter, temperature, oxygen, microbial competition and moisture. ${ }^{5}$ Many authors have quoted that bacteria like Salmonella spp., faecal coliforms and Enterococcus spp. can be found in Cow dung. ${ }^{5}$ Also, bacteria like Campylobacter spp., Listeria monocytogenes and Yersinia enterocolitica can also be traced in Cow dung. ${ }^{7}$ Among parasites, the most important and widely prevalent ones in Cow dung are Ostertagia sp., Trichostrongylus sp., Cooperia sp., Oesophagostomum spp., Taenia spp., Toxocara spp., Giardia spp. and Fasciola spp. ${ }^{1}$ Eggs like Toxocara vitulorum are important and often found in stool of calves and adult cows also. ${ }^{8}$ Cryptosporidium is an acid fast protozoan parasite that commonly infects calves and other mammalian hosts, and can be transmitted to man. ${ }^{9}$ Cryptosporidiosis poses a significant problem in dairy calves where the prevalence of infection is high, and leads to losses due to increased treatment costs and occasionally can even result in mortality. ${ }^{9}$ The temperature, humidity and rainfall of tropical countries are highly favourable for parasites. Like other diseases, parasitic infections cause economic losses like mortality in cattle, stunted growth, loss of body weight gain leading to poor quality of skin, decreased milk and meat production. ${ }^{1,10}$ In a study in Bangladesh, about $40 \%$ of cow dung samples showed one or more parasites. ${ }^{1}$ About $30 \%$ of these samples showed coccidian parasites in Cow dung. ${ }^{1}$ Also, raw manure and improperly treated manure can act as a source of contamination of soil, air and water by pathogens, which in turn can result to critical public health issues. ${ }^{5}$

\section{Our experiences}

We are also studying the pathogenic bacterial and parasitic flora in cow dung and have found parasites like Entamoeba polecki, Entamoeba histolytica and Cryptospiridium spp. in about $20 \%$ of cow 
dung samples in periurban households. One egg of Toxocara spp. was also found. The pathogenic bacteria that have been found are fecal Escherichia coli and Bacillus cereus.

\section{Ways to decontaminate cow dung}

The best management practices to reduce pathogens in livestock wastes focus in three angles: reducing pathogens in the animals, during manure collection and storage and lastly during land application of manure. ${ }^{5}$ Even a small bit of reduction in pathogens in cow dung can make manure and pit soil much safer for humans. Such methods are air drying, Ultraviolet irradiation ad anaerobic storage in lagoons and tanks. ${ }^{5}$ Other physical methods like Pasteurization and chemical methods like treatment by Lime and Hydrogen peroxide can also effectively reduce microbial load in cow dung. ${ }^{5}$ Out of these, lime treatment is advocated because of its cost-effectiveness, easy disposal of the treated manure as well as the resultant reduction in soil acidity. ${ }^{1}$

\section{Discussion}

Hence cow dung is highly infectious to man and should be dealt with very carefully. It has been estimated and shown also that about a hundred infections may be transmitted from animal to animal and that more than 150 infectious diseases may also be transmitted as well from animal to man. ${ }^{12}$ So the people handling the cow dung samples are at great risk of acquiring infections also. Such studies are rare especially in India, Our study is hence quite important in this regard. However we will carry out further research in this aspect since this is an important avenue of public health research. In the field of one health it demands more importance.

\section{Conclusion}

Cow dung is a potent source of bacteria and parasites and hence should be handled and disposed carefully. Its use in farms and households as bio fertilizer and biofuel should be restricted.

\section{Acknowledgments}

Authors acknowledge the contributions of workers in this regard whose studies have been referenced and cited.

\section{Conflicts of interest}

None.

\section{References}

1. Das P, Khanum H, Mahmud ZH, et al. Presence of bacteria and parasites in cow dung and pit soil, a usual mean of bio-fertilizer in different area of Bangladesh. Biores Commun. 2016;2(2):238-242.

2. Two-thirds of rural households still use firewood for cooking, says NSSO. 2015.

3. Jeffery R, Jeffery P, Lyon A. Taking Dung-Work Seriously: Women's Work and Rural Development in North India. Economic and Political Weekly. 1989;24(17):WS32-WS37.

4. Pyati AR. Those dung cakes could be harmful: Study. 2012.

5. Manyi-Loh CE, Mamphweli SN, Meyer EL, et al. An Overview of the Control of Bacterial Pathogens in Cattle Manure. Int J Environ Res Public Health. 2016;13(9):843.

6. Godwin D, Moore JA. Manure Management in Small Farm Livestock Operations. Oregon State University Extension Service; Corvallis, OR, USA. 1997. 8649

7. Pachepsky YA, Sadeghi AM, Bradford SA, et al. Transport and fate of manure-based pathogens: Modeling perspective. Agric. Water Manag. 2006;86(1-2):81-92.

8. TOXOCARA VITULORUM, parasitic roundworms of CATTLE. Biology, prevention and control. Neoascaris vitulorum.!

9. Venu R, Latha BR, Basith SA, et al. Factors influencing on prevalence of Cryptosporidium infection in south Indian dairy calves. $J$ Parasit Dis. 2013;37(2):168-172.

10. Nooruddin, M, Baki MA, Das JG. Clinicopathological studies of an outbreak of trichuriasis in cow calves. Indian Journal of Veterinary Medicine. 1987;7:116-119.

11. Spiehs M, Goyal S. Best Management Practices for Pathogen Control in Manure Management Systems. University of Minnesota Extension; St. Paul, MN, USA: 2007. M1211.

12. Strauch, D, Ballarini, G. Hygienic aspects of the production and agricultural use of animal wastes. Zentralbl Veterinarmed B. 1994;41(3):176-228.

\section{Funding}

None. 